\title{
In Praise of the Phytogenic Medicinal Plant Syzygium Aromaticum: A Review
}

\author{
Sonali Bhakta ${ }^{1, a, *}$, Shonkor Kumar Das ${ }^{2, b}$ \\ ${ }^{1}$ Department of Anatomy and Histology, Faculty of Veterinary Science, Bangladesh Agricultural University, Bangladesh
} *Corresponding author

\begin{tabular}{|c|c|}
\hline A R T I C L E I N F O & A B S T R A C T \\
\hline $\begin{array}{l}\text { Keywords: } \\
\text { Syzygium aromaticum } \\
\text { Clove } \\
\text { Herbal } \\
\text { Medicine }\end{array}$ & $\begin{array}{l}\text { Syzygium aromaticum commonly known as Clove is considered to be the most precious spice } \\
\text { among others, which has been continued to be utilized for centuries for different biological and } \\
\text { therapeutic purposes. It is a tropical tree which belongs to the Myrtaceae family and natively } \\
\text { originated from Indonesia. However, in current times it is found in a few other places of the world } \\
\text { including Brazil. Clove is viewed as perhaps the most extravagant source of phenolic mixes, for } \\
\text { example, eugenol, eugenol acetic acid derivatives and so on. These mixtures have incredible } \\
\text { potential for restorative, organic and other rural applications. In this review we have tried to figure } \\
\text { out some of the important medicinal or therapeutic as well as phytobiotic and agricultural } \\
\text { utilizations of the products prepared from Clove. We have tried to give an extra emphasis on the } \\
\text { application of clove as a product of herbal contraception however for this purpose dose of the extract } \\
\text { (either aqueous or ethanolic) of clove plays the vital role in this case. Although for establishing or } \\
\text { making clove products commercially available as a safe product for herbal contraception or other } \\
\text { medicinal impacts, more studies are required, and it could open a new era in the field of herbal } \\
\text { medicine that would be much safer and feasible. }\end{array}$ \\
\hline
\end{tabular}

Biological

sonali.dvm@gmail.com (iD) https://orcid.org/0000-0002-1177-068X

| $@$ skdas76@yahoo.com (i) https://orcid.org/0000-0001-8958-4847

(c) (1) () This work is licensed under Creative Commons Attribution 4.0 International License

\section{Introduction}

The indigenously grown or herbal medication has become famous now a days. Regardless of amazing specialized movement, the usage of the common items with remedial properties is as old as human progress and even roughly 70 $80 \%$ of the total population keeps relying upon non-traditional medicinal products of home-grown source for their essential therapeutic services (Mishra et al., 2013). Spices for instance clove, mint, oregano, thyme, cummin cinnamon and so on have been utilized for a considerable length of time as a nourishment additive specially for the medicinal values in case of both human and Agricultre. Clove (Syzygium aromaticum) is a spice which has many medicinal/therapeutic properties. This is an air dried, unopened, pink flowering bud of the tree Syzygium aromaticum (Figure 1).

Clove is originated from tropical evergreen tree of the family Myrtaceae and its little ruddy brown blossom buds, which are utilized as a flavor. From the most pungent flavor exchanges clove is considered to be the foremost vital among the others and accepted to be indigenous to the Moluccas, or Zest Islands, of Indonesia. For its solid smell and sharp taste, cloves are utilized to flavor numerous cuisines, especially meats and pastry kitchen items in Europe.

\section{History and Trading of Syzygium Aromaticum}

Primarily, a clearly dated archeological discovery of clove is considerably goes with proves which have two illustrations, found at an exchanging harbour in Sri Lanka, dated to around 900-1100 AD (Andaya et al., 1993). A prior detailed discovery, in Syria, dated to around $1700 \mathrm{BC}$, though is not accepted to be a clove (Lape et al., 2010, Kingwell-Banham, 2019).

Until advanced times, discovery of clove was restricted on some islands within the Moluccas (verifiably called the Flavor Islands), counting Bacan, Makian, Moti, Ternate, and Tidore (Turner, 2004). In fact, the clove tree that specialists accept is the most seasoned within the world, named Afo, is on Ternat; the tree is between 350 and 400 yrs, a long time old (Worrall, 2012). Sightseers are told that seedlings from this exceptionally old tree were stolen by a Frenchman named Pierre Poivre in 1770, exchanged to the Isle de France (Mauritius), and after that to Zanzibar, which was once the world's biggest producers of cloves (Worrall, 2012).

Until cloves were harvested outside of the Maluku Islands, they were traded like oil, with a purpose of 
exportation (Worrall, 2012). As the Dutch East India Company set its control of the flavor trade inside the seventeenth century, they searched for an impressive plan of action in cloves as they had in nutmeg. But the trading policy was, "not at all like nutmeg and mace, which were constrained to the diminutive Bandas, clove trees developed all over the Moluccas, and the exchange in cloves was constrained policing powers of the organization in the past".

\section{Cultivation and Harvesting}

The clove tree is cultivated in beach front extents at most noteworthy rises of $200 \mathrm{~m}$ over the sea level. The age of bloom buds, which is the marketed part of this tree, starts after $4 \mathrm{~m}$ quite a while of farm. Bloom buds are gathered inside the improvement stage before blooming. The arrangement probably should be possible truly or artificially intervened using a brand name phytohormone which frees ethylene inside the vegetal tissue, making new development of events (Kamatou et al., 2012). Nowadays, the high producing countries of clove are Indonesia, India, Malaysia, Sri Lanka, Madagascar and Tanzania phenomenally the Zanzibar Island (Filho et al., 2013). Clove in Brazil, is refined inside the upper east region, inside the province of Bahia inside the areas of Valença, Ituberá, Taperoá, Camamu and Nilo Peçanha, where around 8000 hectares are created, delivering close around 2500 tons for each year (Oliveira et al., 2007, Oliveira et al., 2009).

\section{Phytochemical Constituents of Syzygium Aromaticum}

Clove considered to be one of the major vegetal sources of phenolic mixes such as flavonoids, hidroxibenzoic acids, hidroxicinamic acids and hidroxiphenyl propens. Eugenol is the most bioactive compound of clove, which is found in fixations stretching out from 9381.70 to 14650.00 mg per $100 \mathrm{~g}$ of new plant (Diego et al., 2014). As for the phenolic acids, gallic acid is the compound found in higher amount (783.50 mg/100 g new weight). Albeit, other gallic acid derivates as hidrolizable tannins are appeared to be in higher amounts as well (2375.8 mg/100 g) (Shan et al., 2005). Caffeic, ferulic, elagic and salicylic acids are the other phenolic acids found in Clove. Flavonoids such as kaempferol, quercetin and its derivates (glycosilated) are found in clove in lower extracted amounts also. Extraction of essential oil up to $18 \%$ can be found inside the buds of blossom clove. The maximum part, $89 \%$ of the clove essential oil is eugenol and 5\% to $15 \%$ is eugenol acid derivatives and $\beta$-cariofileno (Jirovetz et al., 2006). Another crucial compound found in essential oil of clove is $\alpha$-humulen, which is up to $2.1 \%$. Other slightly extracted mixes appear in lower levels in clove are other essential oils such as $\beta$-pinene, limonene, farnesol, benzaldehyde, 2 heptanone and ethyl hexanoate (Figure 2).

Therapeutic Uses of Clove or Syzygium Aromaticum

Dietary utilization of cloves can help in the alleviation of a high level of immunities, both internal and external (Neveu et al., 2010). In addition, this phytogenic element can be used either as a whole, ground form, or can be used as an essential oil.
Some of the most important uses of Clove in the field of medical sciences or as therapeutic components are given below:

\section{Utilization As Rust Inhibitor or Antioxidant}

These medicical plants are the sort of substance with higher polyphenol compound taken after by normal items, seeds and vegetables. Among flavors, clove has all the remarks of being the higher source of polyphenols and a mixture of anti-cancer compounds. Clove (buds) has the higher cancer prevention agent and polyphenol substance, (168.660+/- 0.024) tetraethylammonium chloride (mmol of Trolox $/ 100 \mathrm{~g}$ dried weight) and (14.380+/ - 0.006) $\mathrm{g}$ of gallic corrosive (reciprocals $/ 100 \mathrm{~g}$ of dried weight), respectively. Ethanol and aqueous concentrates of clove and lavender at the rate of 20,40 and $60 \mu \mathrm{g} / \mathrm{mL}$ showed up impediments up to $95 \%$ when attempted as metal quelants, superoxide radical absorbant and scavenging the DPPH radical. The successful cell reinforcement development of the two concentrates might be credited to the strong hydrogen producing limit, metal chelating capacity and scavangin of free radicals, hydrogen peroxide and superoxide (Gulcina et al., 2004).

Anti-cancer compounds are fundamental components for the treatment of memory deficiencies achieved by oxidative pressing factors (Abdel Wahhab et al., 2005). Earlier treatment with clove basic oil diminishes the oxidative pressure surveyed by malondialdehyde and decreased glutathione levels in cerebrum of mice. That review said that clove oil could return memory and learning shortfalls brought about by scopolamine in short and since a long-time age, because of the reduction in the oxidative pressure (Mehta et al., 2010). These works exhibited the invaluable sides of the utilization of clove as a rich wellspring of cell fortifications for the treatment of oxidative pressing factor decided memory setbacks.

Extricates from clove buds seem to be utilized as cancer prevention agents such as food antioxidants (Halder et al., 2011). Controlled delivery of cancer prevention agents could be accomplished by embodied clove powder got by utilizing maltodextrin.

\section{Germicidal Activity of Clove}

The antimicrobial or germicidal exercises of clove have been shown against a couple of bacterial and infectious strains. The watery solution of clove at $3 \%$ seemed to have bactericidal effect against all the food borne pathogens such as Escherichia coli, Staphylococcus aureus and Bacillus cereus. Definitely $1 \%$ mixture of clove extract seems to be indicated as an extraordinary inhibitory activity against various strains of microbes (Chatterjee et al., 2013).

The antibacterial action of clove, oregano (Origanum vulgare), narrows (Pimenta racemosa) and thyme (Thymus vulgaris) esssential oil was tried against E. coli O157:H7 demonstrating the various evaluations of hindrance of these basic oils (Sofia et al., 2007). Clove extracts containing eugenol and carvacrol epitomized in a non-ionic surfactant were tried against four strains of two significant foodborne pathogens, E. coli O157:H7 and Listeria monocitogenes, results fortify the work of eugenol to hinder the development of these microorganisms on surfaces of the various food stuffs (Burt et al., 2003). 

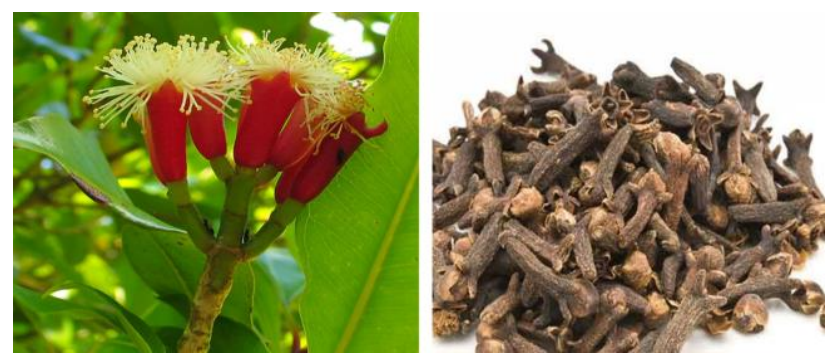

Figure 1. Syzygium aromaticum flower before and after drying

\section{Antifungal Usability of Clove}

Rana et al. chosen the antifungic activity of clove oil in a few strains and showed this size of reasonableness Mucor sp.>Microsporum gypseum $>$ Fusarium monoliforme NCIM 1100>Trichophytum rubrum $>$ Aspergillus sp. $>$ Fusarium oxysporum MTCC 284 (Rana et al., 2011). The chromatographic examinations introduced that for the antifungic action, eugenol was the principal compound, to be dependent on because of lysis of the spores and micelles. Genuinely the same component having the activity of film interruption and disfigurement of macromolecules created by eugenol was primarily introduced by Devi et al. (2010).

The anticandidal activity of eugenol and carvacrol was tried in a vaginal candidiasis model, microbial and histological techniques were used to recognize the tests with the controls. The outcomes suggest that eugenol and carvacrol may be a promising antifungal operator for treatment and prophylaxis of vaginal candidiasis (Chami et al., 2004).

In extension to the broad-spectrum activity of eugenol against microbes or microscopic creatures, an examination introduced that eugenol and cinnamaldehyde at $2 \mu \mathrm{g} / \mathrm{mL}$ subdued the advancement of 31 strains of Helicobacter pylori, after $9 \mathrm{~h}$ and $12 \mathrm{~h}$ of brooding, moreover the action ismuch more intense than that of amoxicillin without any baleful effect. To exert the antimicrobial activity those mixtures were tried at low $\mathrm{p}$ as Helicobacter pylori stays in the stomach (Ali et al., 2005).

\section{Analgesic Effect of Clove (Antinociceptive)}

The work of clove as analgesic or pain relief have been accounted for since the thirteenth century, for toothache, agony of joint and antispasmodic, eugenol is the the major compound responsible for this activity. The progression of the component has been credited to the order of calcium and chloride diverts in ganglionar cells (https://www.herbwisdom.com/herb-cloves.html). The voltage dependant effects of eugenol in sodium and calcium alterations and in receptors imparted inside the trigeminal ganglio additionally added to the agony soothing impact of clove (Li et al., 2008). Different outcomes indicated that the pain-relieving impact of clove is because of the activity as capsaicin agonist (Ohkubo et al., 1997). The fringe antinociceptive action of eugenol was accounted for by Daniel et al. indicating noteworthy movement at dosages of 50, 75 and $100 \mathrm{mg} / \mathrm{kg}$ (Daniel et al., 2009). At the point when the oil is applied hastily to the body, it can mitigate torment from stiffness, gout, or different agonies began from Inflammation.

\section{Antiviral Effect of Clove}

Eugeniin, a compound extricated from S. aromaticum and from Geum japonicum has the antiviral movement, which was tried against herpes infection strains being compelling at $5 \mu \mathrm{g} / \mathrm{mL}$. It was anticipated that eugeniin normally assaults viral DNA by inhibiting viral DNA polymerase synthesis mechanism (Kurokawa et al., 1998).

In another investigation, liquid extrricates of $\mathrm{S}$. aromaticum (L.) Merr. et Perry when joined with acyclovir demonstrated solid antiherpes simplex infection type 1 (HSV-1) movement among others and different plants were Geum japonicum Thunb., Rhus javanica L., and Terminalia chebula Retzus. This synergic activity was more grounded in cerebrum than in skin and it was also shown that those blends were not noxious to mice (Mishra and Singh, 1995).

\section{Aid in Digestion}

Utilization of Clove can soothe and relax the inner membrane of the intestines, through this it can also help in resolving the upset stomach. As clove can act as an antimicrobial agent, so killing opportunustic parasites and bacteria in the digestive tract that hamper the digestion, can also be executed by the clove oil/ethanolic or aqueous clove extract. In appropriate dosage, it can help to relieve excessive gas bloating.

\section{Relieving Dental Pain in Gum}

Clove has shown to have analgesic properties. This property is especially effective for tooth pain. To treat any disease of gum, whole clove can be applied directly to the particular areas of the gum. Gum having thin skinned membrane absorbs the oil of clove and thus exert the analgesic effect, so the topically get relief from pain. That's the reason almost all the good tooth pastes of renowned companies contain clove as an essential element. Although clove can also be used to outer membrane of the skin to help in case of sun burn or poison ivy, but it this case clove has a low effectiveness.

\section{Effect of Clove on as a Contracpetive Phytobiotic Compound}

S. aromaticum or clove has a positive impact in case of the reproductive system. Although very few researches have been conducted on the issue. But still some works have been done, here we are trying to emphasize on those studies.

A study focusing on male genital system found that $S$. aromaticum flower bud caused dose-dependent biphasic effect on male reproductive system in mice; lower dose of $S$. aromaticum appears to be stimulatory, while the higher doses have adverse effect on male reproduction. The results suggested that the lower dose of $S$. aromaticum may have androgenic effect (Mishra and Singh, 2006). They have found that, in case of the body weight there was no effect of the dose of the oil extract of clove treated mouse and the control. Yet, on the reproductive organ's weight it had sway, so when $15 \mathrm{mg}$ portion was given to the treated mice loads of epididymis and original vesicle was practically same with the control. Be that as it may, in treated mice with higher dosages $(30 \mathrm{mg}$ and $60 \mathrm{mg}$ ) loads decreased essentially contrasted with controls. So, they reported that the impact of clove separate on the 
regenerative framework works absolutely in a subordinate way.

Another group of researchers in their study had observed that, a distinguishable reduction in the number of spermatozoa in cauda epididymis of mice treated with higher dosages of $S$. aromaticum is likely to be caused by the suppressive effect on spermatogenesis, (Mishra and Singh, 1995) mean while modification in sperm motility and morphology might have resulted from disturbances in functional environment of epididymis in the treated mice (Rajlakshmi et al., 1992). It is worthy to mention here that Buch et al., (Buch et al., 1988) have also reported about the spermicidal property of $S$. aromaticum oil on ejaculated human spermatozoa.

Secretory function of epididymis and seminal vesicle is completely dependent on androgen (Lo and Lamb et al., 2004), however biosynthesis of testosterone is also dose dependent, and at lower dose it is stimulated while suppressed at higher doses.

Previously a study has been done by another researcher group, using a combination of Ricinus communis, Abrus precatorius and Syzygium aromaticum on the reproductive system of male Swiss albino mice. Where Bhakta et al., (2019) has shown that the gross weight, width and length of testes was reduced in case of the treated mice compared to the control one. Moreover microscopically, changes in a single focus of the herbal extract treated testis showed that the number of the seminiferous tubules decreased in the treated group mice compared to the control (Bhakta et al., 2019). The amount of the spermatozoa within the lumen of the seminiferous tubules also reduced, in case of the treated mice it was $35 \%$ whereas in case of the control mice it was $70 \%$. Along with that fibrous thickening of the membrane was found surrounding the seminiferous tubules and at the same time, vacuolization within the seminiferous tubules was also found in the treated mice, which were not the features in case of the control mice. In the control group, huge number of the sertoli cells within the seminiferous tubules and the leydig cells in between the seminiferous tubules were found, but in the treated group $\mathrm{T}$ there were reduction of the number of the sertoli and leydig cells. In this experiment a total of $4.4 \mathrm{mg} / \mathrm{kg}$ Body weight of the combined herbal extract was fed per mice for the treatment purpose. In this case also it could be a dose dependent effect of the herbal extracts on the testes of male mice, which could be recovered by reducing the dose to be treated with (Bhakta et al., 2019).

Another analyst additionally attempted to discover the impact of Syzygium aromaticum on the regenerative arrangement of male mice (BALB/c), for the reason, the mice were then treated with 250,500 and $1000 \mathrm{mg} / \mathrm{kg} /$ day of $S$. aromaticum remove for 34 days.

They did the hormonal test where they found, the creatures were taken care of with 500 and $1000 \mathrm{mg} / \mathrm{kg} /$ day of $S$. aromaticum remove and demonstrated a huge lessening in testosterone level contrasted and the negative control $(\mathrm{P}<0.05)$ (Delghani et al., 2012).

With respect to quality, the organization of 1000 $\mathrm{mg} / \mathrm{kg} /$ day of $S$. aromaticum separate prompted a huge decline in the sperm check $(\mathrm{P}<0.05)$ contrasted and the other two unique portions and furthermore the negative control. The semen examination of the creatures treated with $1000 \mathrm{mg} / \mathrm{kg} /$ day indicated a critical lessening in the level of the sperms. The seminiferous tubules in the testicles of creatures that were taken care of with 1000 $\mathrm{mg} / \mathrm{kg} /$ day contained less sperms contrasted and those of the negative control creatures $(\mathrm{P}<0.05)$. If there should be an occurrence of the test mice the fluid extraction of Clove was taken care of while Ethanolic concentrate of $S$. aromaticum can upgrade male sexual movement. Hence, it has been utilized in home grown medication as a Spanish fly in such instances of male sexual issue or debility (Tajuddin et al., 2003). Moreover, from this study it was also proven that the effect of $S$. aromaticum is highly dependent on the dose. Beside these effects of the $S$. Aromaticum, it has also some agricultural effects and it can also act as a larvicidal. Such as:

\section{Agricultural Use of Clove Oil}

Nowadays, the utilization of the pesticides or insecticides has been increased drastically in the agricultural fields for the purpose harvesting maximum crop. But the chemicals which are used as the pesticides have many devastating side effects to the human body as well to the field itself.

In this regard, the clove essential oil can also be used as insecticide for killing the bugs and other harmful insects which cause harm to the crops in the agricultural fields. Park and Shin detailed the chance of work of clove basic oil to control the japonesse terminte Reticulitermes speratus Kolbe (Park and Shin, 2005). Additionally, Eamsobhana et al. seen that $5 \%$ clove fundamental oil have $100 \%$ of repellent movement against the chigger Leptotrombidium imphalu. So, clove oil can be a more secure and less expensive option in contrast to manufactured anti-agents which are generally utilized and have some hurtful symptoms to the gathered yield just as to the human wellbeing in since quite a while ago run (Eamsobhana et al., 2009).

\section{Larvicidal Effect of Clove Oil}

In the recent time Dengue, a mosquito borne disease, has become a common disease especially in the south East Asia particularly Bangladesh and India, previously malaria was at that chart. But for last two to three years the problem of Dengue has increased a lot particularly during the rainy season. Many chemical sprays are there to kill the larva of the mosquito, but those are highly toxic and may also have some long run harmful effects on the human health and also to the environment. In this regard, a botanic origin of product is highly needed.

Past investigations have indicated that a detailing containing $10 \%$ of clove basic oil has been exhibited to be compelling against the bit of Aedes aegypti (L.) and Anopheles dirus Peyton and Harrion with an insurance time of (80.33+/- 10.56) and (60.00+/- 10.00), separately. Eugenol, eugenol acetic acid derivation and betacaryophyllene were viable in repellency of red imported fire ants Solenopsis invicta (Hymenoptera: Formicidae) (Kafle and Shih et al., 2003). Clove oil was additionally demonstrated powerful for repellent of pestiferous social wasps Vespula pensylvanica (Saussure) and paper wasps for the most part Polistes dominulus (Christ) (Zhang et al., 2013). So, in this circumstance the clove oil could be a viable option for being utilized as a larvicidal operator. 


\section{Conclusion}

According to the presented information in this review we could conclude that $\mathrm{S}$. aromaticum is a highly potential candidate of the herbal medicine among the other plants who have medicinal values as it shows antioxidant, antimicrobial, antifungal, antiviral, analgesic properties. Along with these it also aids in digestion as well as relief from blot, relief tooth pain. Most importantly it has a very vital impact on the reproductive system although according to the previous studies it has been proven that its effect is completely dependent on the dose. Although it could be a potential source of herbal contraceptive agent. Furthermore, it has role in the agriculture and also as larvicidal agent. Its proven biological as well as medicinal activities suggest to develop the commercial form of medicine for both the human and animals but of course for any herbal product the key point is to maintain the dose which distinguishes a drug from being poison. So, for more vast utilization of clove originated products, more rigorous experiments and also studies are needed, which will also open up the secret why this herbal plant has been used for centuries.

\section{Acknowledgements}

The research work was supported with the grants from the Ministry of Education and Ministry of Science and Technology, Bangladesh.

\section{Conflicts of interest}

The authors declare that there is no conflict of interest towards the publication of this article.

\section{References}

Mishra RK, Singh SK. 2013. Reproductive effects of lipid soluble components of Syzygium aromaticum flower bud in male mice. J Ayurveda Integr Med, 2013; 4: 94-8.

Andaya LY. 1993. "Cultural State Formation in Eastern Indonesia". In Reid, Anthony (ed.). Southeast Asia in the early modern era: trade, power, and belief. Cornell University Press 1993; ISBN 978-0-8014-8093-5.

Lape PV. 2010. Political dynamics and religious change in the late pre-colonial Banda Islands, Eastern Indonesia. World Archaeology, 2010; 32(1): 138-155.

Kingwell-Banham E. 2019. "World's oldest clove? Here's what our find in Sri Lanka says about the early spice trade". The Conversation, 2019.

Turner J. 2004. Spice: The History of a Temptation. Vintage Books, 2004; pp. xxvii-xxviii. ISBN 978-0-375-70705-6.

Worrall S. 2012. The world's oldest clove tree. BBC News Magazine, 2012.

Kamatou GP, Vermaak I, Viljoen AM. 2012. Eugenol from the remote Maluku Islands to the international market place: a review of a remarkable and versatile molecule. Molecules, 2012; 17(6): 6953-6981.

Filho GA, Cesar JO, Ramos JV. 2013. Cravo from India. Itabuna: CEPLAC, 2013. Available from: http://www.ceplac.gov.br/ radar.htm.

Oliveira RA, Oliveira FF, Sacramento CK. 2007. Essential oils: prospects for agribusiness spices in Bahia. Bahia Agric, 2007; 8(1): 46-48.

Oliveira RA, Reis TV, Sacramento CK, Duarte LP, Oliveira FF. 2009. Volatile chemical constituents of rich spices in eugenol. Rev Bras Farmacognosia, 2009; 19(3): 771-775.
Diego Francisco CR, Claudia RFS, Wanderley PR. 2014. Clove (Syzygium aromaticum): a precious spice. Asian Pac J Trop Biomed, 2014; 4(2): 90-96.

Shan B, Cai YZ, Sun M, Corke H. 2005. Antioxidant capacity of 26 spice extracts and characterization of their phenolic constituents. J Agric Food Chem, 2005; 53(20): 7749-7759.

Jirovetz L, Buchbauer G, Stoilova I, Stoyanova A, Krastanov A, Schmidt E. 2006. Chemical composition and antioxidant properties of clover leaf essential oil. J Agric Food Chem, 2006; 54(17): 6303-6307.

Neveu V, Perez-Jiménez J, Vos F, Crespy V, du Chaffaut L, Mennen L, et al. 2010. Phenol-Explorer: an online comprehensive database on polyphenol contents in foods. Database, 2010; bap024.

Gülçina İ, Şatb İG, Beydemira Ş, Elmastaşc M, Küfrevioglu Öİ. 2004. Comparison of antioxidant activity of clove (Eugenia caryophylata Thunb) buds and lavender (Lavandula stoechas L.). Food Chem, 2004; 8(3): 393-400.

Abdel-Wahhab MA, Aly SE. 2005. Antioxidant property of Nigella sativa (black cumin) and Syzygium aromaticum (clove) in rats during aflatoxicosis. J Appl Toxicol, 2005; 25(3): 218-223.

Mehta KD, Garg GR, Mehta AK, Arora T, Sharma AK, Khanna N. 2010. Reversal of propoxur-induced impairment of memory and oxidative stress by 4'-chlorodiazepam in rats. Naunyn Schmiedebergs Arch Pharmacol, 2010; 381(1): 1-10.

Halder S, Mehta AK, Kar R, Mustafa M, Mediratta PK, Sharma KK. 2011. Clove oil reverses learning and memory deficits in scopolaminetreated mice. Planta Med, 2011; 77(8): 830-834.

Chatterjee D, Bhattacharjee P. 2013. Comparative evaluation of the antioxidant efficacy of encapsulated and un-encapsulated eugenol-rich clove extracts in soybean oil: shelf-life and frying stability of soybean oil. J Food Eng, 2013; 117(4): 545-550.

Sofia PK, Prasad R, Vijay VK, Srivastava AK. 2007. Evaluation of antibacterial activity of Indian spices against common foodborne pathogens. Int J Food Sci Technol, 2007; 42(8): 910-915.

Burt SA, Reinders RD. 2003. Antibacterial activity of selected plant essential oils against Escherichia coli O157:H7. Lett Appl Microbiol, 2003; 36(3): 162-167.

Pérez-Conesa D, McLandsborough L, Weiss J. 2006. Inhibition and inactivation of Listeria monocytogenes and Escherichia coli O157:H7 colony biofilms by micellar-encapsulated eugenol and carvacrol. J Food Prot, 2006; 69(12): 2947-2954.

Rana IS, Rana AS, Rajak RC. 2011. Evaluation of antifungal activity in essential oil of the Syzygium aromaticum (L.) by extraction, purification and analysis of its main component eugenol. Braz J Microbiol, 2011; 42(4): 1269-1277.

Devi KP, Nisha SA, Sakthivel R, Pandian SK. 2010. Eugenol (an essential oil of clove) acts as an antibacterial agent against Salmonella typhi by disrupting the cellular membrane. J Ethnopharmacol, 2010; 130(1): 107-115.

Chami F, Chami N, Bennis S, Trouillas J, Remmal A. 2004. Evaluation of carvacrol and eugenol as prophylaxis and treatment of vaginal candidiasis in an immunosuppressed rat model. J Antimicrob Chemother, 2004; 54(5): 909-914.

Ali SM, Khan AA, Ahmed I, Musaddiq M, Ahmed KS, Polasa H, et al. 2005. Antimicrobial activities of eugenol and cinnamaldehyde against the human gastric pathogen Helicobacter pylori. Ann Clin Microbiol Antimicrob, 2005; 4: 20. https://www.herbwisdom.com/herb-cloves.html

Li HY, Lee BK, Kim JS, Jung SJ, Oh SB. 2008. Eugenol inhibits ATPinduced P2X currents in trigeminal ganglion neurons. Korean J Physiol Pharmacol, 2008; 12(6): 315-321.

Ohkubo T, Shibata M. 1997. The selective capsaicin antagonist capsazepine abolishes the antinociceptive action of eugenol and guaiacol. J Dent Res, 1997; 76(4): 848-851.

Daniel AN, Sartoretto SM, Schimidt G, Caparroz-Assef SM, Bersani-Amado CA, Cuman RK. 2009. Anti-inflamatory and antinociceptive activities of eugenol essential oil in experimental animal models. Rev Bras Farmacogn, 2009; 19(1B): 212-217. 
Kurokawa M, Hozumi T, Basnet P, Nakano M, Kadota S, Namba T, et al. 1998. Purification and characterization of eugeniin as an antiherpesvirus compound from Geum japonicum and Syzygium aromaticum. J Pharmacol Exp Ther 1998; 284(2):728-735.

Kurokawa M, Nagasaka K, Hirabayashi T, Uyama S, Sato H, Kageyama T, et al. 1995. Efficacy of traditional herbal medicines in combination with acyclovir against herpes simplex virus type 1 infection in vitro and in vivo. Antiviral Res, 1995; 27(1-2): 19-37.

Mishra RK, Singh SK. 2008. Safety assessment of Syzygium aromaticum flower bud (clove) extract with respect to testicular function in mice. Food Chem Toxicol, 2008; 46:3333-3338.

Rajalakshmi M. 1992. Regulation of male fertility: Epididymis as a potential extra-gonadal site. In: Ghosh D, Sengupta J, editors. Frontiers in reproductive physiology. New Delhi: Wiley Eastern Limited, 1992; 63-66.

Buch JG, Dikshit RK, Mansuri SM. 1988. Effect of certain volatile oils on human spermatozoa. Indian J Med Res, 1988; 87:361-363.

Lo KC, Lamb DJ. 2004. The testis and male accessory sex organs. In: Strauss LF, Barbieri RL, editors. Yen and Jaffe's Reproductive Endocrinology. Pennsylvania: Elsevier Saunders, 2004; 5: 367-87.

Bhakta S, Awal A, Das SK. 2019. Herbal contraceptive effect of Abrus precatorius, Ricinus communis, and Syzygium aromaticum on anatomy of the testis of male Swiss albino mice. J Adv. Biotechnol. Exp. Ther., 2019; 2(2): 36-43.
Dehghani F, Heshmatpour A, Panjehshahin MR, Talaei-Khozani T. 2012. Toxic effects of water/alcoholic extract of Syzygium aromaticum on sperm quality, sex hormones and reproductive tissues in male mouse. IUFS J Biol, 2012; 71(2): 95-102.

Tajuddin AS, Latif A, Qasmi IA. 2003. Aphrodisiac activity of $50 \%$ ethanolic extracts of Myristica fragrans Houtt. (nutmeg) and Syzygium aromaticum (L) Merr. and Perry. (clove) in male mice: a comparative study. BMC Complementary and Alternative Medicine, 2003; 46: 3333-3336.

Park IK, Shin SC. 2005. Fumigant activity of plant essential oils and components from garlic (Allium sativum) and clove bud (Eugenia caryophyllata) oils against the Japanese termite (Reticulitermessperatus Kolbe). J Agric Food Chem, 2005; 53(11): 4388-4392.

Eamsobhana P, Yoolek A, Kongkaew W, Lerdthusnee K, Khlaimanee N, Parsartvit A, et al. 2009. Laboratory evaluation of aromatic essential oils from thirteen plant species as candidate repellents against Leptotrombidium chiggers (Acari: Trombiculidae), the vector of scrub typhus. Exp Appl Acarol, 2009; 47(3): 257-262.

Kafle L, Shih CJ. 2013. Toxicity and repellency of compounds from clove (Syzygium aromaticum) to red imported fire ants Solenopsis invicta (Hymenoptera: Formicidae). J Econ Entomol, 2013; 106(1): 131-135.

Zhang QH, Schneidmiller RG, Hoover DR. 2013. Essential oils and their compositions as spatial repellents for pestiferous social wasps. Pest Manag Sci, 2013; 69(4): 542-552. 